\title{
Hemocyanin concentrations in marine crustaceans as a function of environmental conditions
}

\author{
David W. Engel ${ }^{1}$, Marius Brouwer ${ }^{2}$, Sean McKenna ${ }^{3}$ \\ ${ }^{1}$ National Marine Fisheries Service, Southeast Fisheries Science Center, Beaufort Laboratory, 101 Pivers Island Road, \\ Beaufort, North Carolina 28516, USA \\ ${ }^{2}$ Duke University Marine Laboratory, Marine Biomedical Center, Beaufort, North Carolina 28516, USA \\ ${ }^{3}$ North Carolina Department of Environment, Health, and Natural Resources, Division of Marine Fisheries, PO Box 1507 , \\ Washington, North Carolina 27889, USA
}

\begin{abstract}
A variety of physiological and biochemical measures have been proposed in the literature as indicators of environmental quality. Here we report studies which were designed to determine if hemolymph hemocyanin concentrations in blue crabs Callinectes sapidus could be correlated with environmental water quality. To this end hemocyanin concentrations were measured in hemolymph of blue crabs collected from North Carolina, Florida, and Texas, USA. Blue crabs from isolated estuarine systems in eastern North Carolina (i.e. Albemarle/Pamlico Sound area) had significantly lower concentrations of hemocyanin in their hemolymph than crabs from reference areas (i.e. Core and Currituck Sounds). These lower concentrations could be correlated with reduced dissolved oxygen and chronic hypoxia, but not with any known sources of anthropogenic contamination. Among crabs from Tampa Bay (Florida) and the Houston (Texas) Ship Channel there was a negative correlation between the degree of industrialization and organic contaminants in the digestive gland and sediments and hemocyanin concentration. In the Houston Ship Channel decreased dissolved oxygen confounded the possible correlation with contaminants. In all areas sampled, lower concentrations of hemocyanin were not correlated with either the apparent health or sex of the crabs or with salinity.
\end{abstract}

\section{INTRODUCTION}

During an investigation of blue crab Callinectes sapidus populations in North Carolina, USA, unusually low concentrations of hemocyanin were measured in the hemolymph of some cohorts of blue crabs (Engel et al. in press). The measurements showed that the concentrations in the crabs collected from the Pamlico River were about one-third of the concentration measured in crabs from Beaufort. This initial observation indicated that the crabs were 'anemic' and possibly under physiological stress.

The importance of hemocyanin to health, survival and normal physiological function of blue crabs, and all other crustaceans, cannot be understated since it serves as the oxygen-carrying protein in the hemolymph. Crustacean hemocyanins are large copper-containing proteins composed of a minimum of 6 subunits, each of 75000 dalton molecular weight. The number of hexamers that make up the hemocyanin molecule varies between 1 and 4 among various groups of crustaceans. The structure and function of hemocyanins have been studied extensively (Van Holde \& Miller 1982, Ellerton et al. 1983, Brouwer 1992). Other researchers have examined the physiological and biochemical processes that control the synthesis and turnover of hemocyanin, and the metabolism of copper and zinc during the molt cycle in blue crabs (Engel \& Brouwer 1987, 1991, 1993, Brouwer et al. 1989).

Extrinsic factors, such as salinity and oxygen concentration in the environment, can have an influence on the concentration of hemocyanin in the hemolymph of crabs. Decreased salinity and hypoxia or lack of oxygen have been shown in the laboratory to cause an increase in hemocyanin in blue crabs (DeFur et al. 1990). In this communication we present data that 


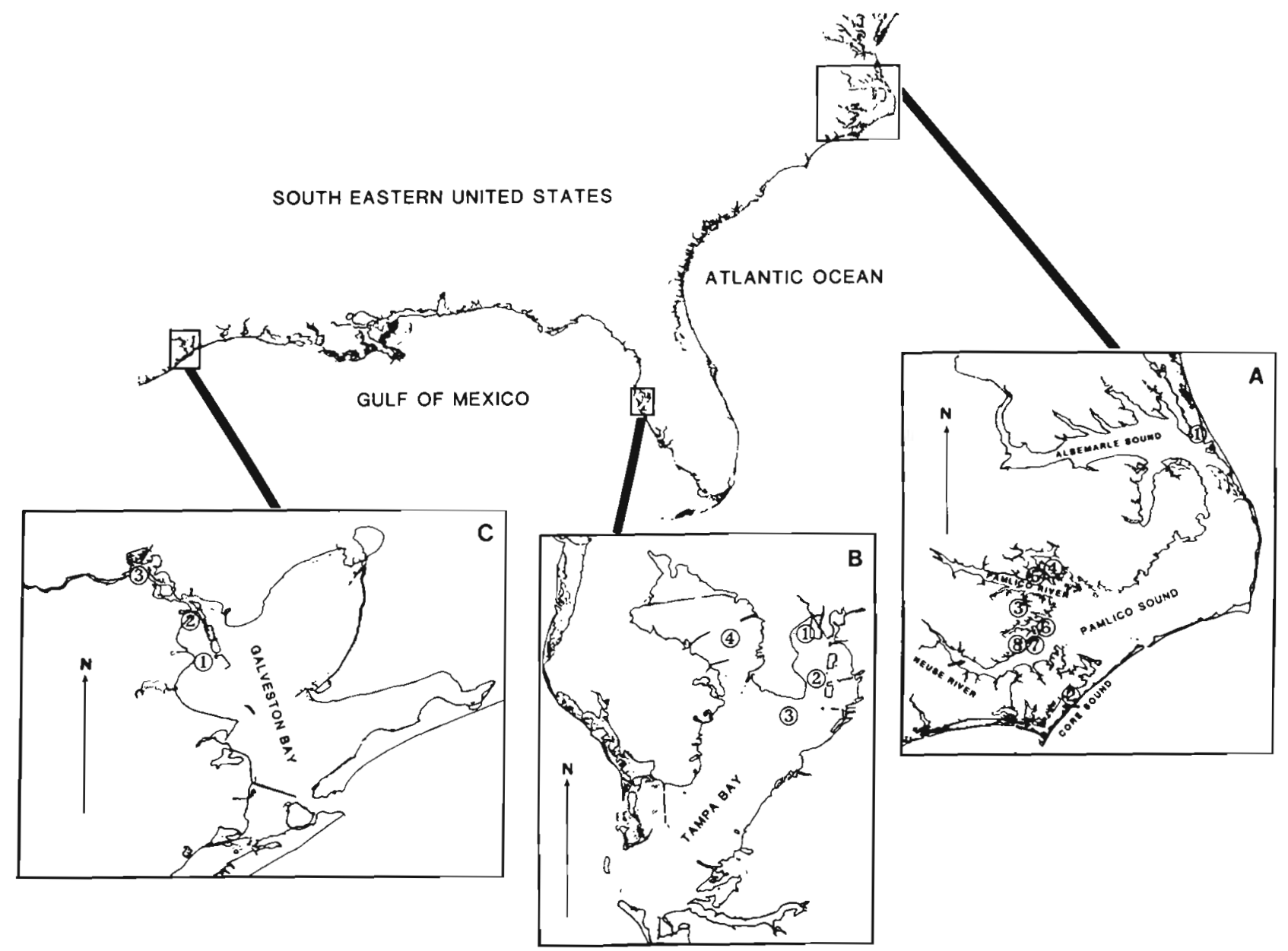

Fig. 1. Locations of blue crab collections in the southeastern United States. (A) Eastern North Carolina. (1) Currituck Sound; (2) Core Sound; (3) South Creek; (4) North Creek; (5) Pungo River; (6) Bay River; (7) Broad Creek; (8) Oriental. (B) Tampa Bay, Florida. (1) North Hillsborough Bay; (2) South Hillsborough Bay; (3) South of Gadsden Point; (4) Old Tampa Bay. (C) Galveston Bay, Houston Ship Channel, Texas. (1) Eagle Point; (2) Morgan Point; (3) Green Bayou

show that while hemocyanin concentrations in blue crabs may be affected by environmental factors, such as salinity and hypoxia, other factors, such as organic contaminants, may be involved. The possible effects of interactions between natural factors and anthropogenic contaminants on blue crab hemocyanin concentrations will be discussed.

\section{METHODS AND MATERIALS}

To study the effect of environmental factors on blue crab hemolymph hemocyanin concentrations, samples were collected at selected sites in the coastal waters of North Carolina, Florida, and Texas (Fig. 1). The collection sites in the different localities were sampled in 1988, 1989, 1990 and 1991. In North Carolina the sites included: Pamlico (South Creek and North Creek) and Pungo Rivers and the Neuse River (Bay River, Oriental and Broad Creek). Reference areas outside of the Pamlico/Neuse area were: Core and Bogue Sounds in 1989 and Core and Currituck Sounds in 1990 and 1991. The substitution of Currituck Sound, a low salinity sampling site, for Bogue Sound made comparisons with the riverine sites more realistic. The routine monthly sampling, from May through October, in North Carolina was conducted by the staff of the N.C. Division of Marine Fisheries. In Florida, hemolymph samples were collected from crabs in 4 locations in Tampa Bay (staff NMFS Seattle Laboratory, Biological Effects Monitoring Program, 1990): North Hillsborough Bay, South Hillsborough Bay, Old Tampa Bay and south of Gadsden Point. In Texas, blue crabs were sampled at 3 locations in the Houston Ship Channel (staff NMFS Beaufort Laboratory, National Benthic Surveillance Program, 1988) which ranged from lightly to heavily contaminated: Eagle Point, Morgan Point and Green Bayou. 
Blue crabs were selected for molt stage. Only intermolt or early premolt $D_{2}$ to $D_{3}$ male crabs and terminal molt female blue crabs without eggs were used. These stages were selected because previous data indicated that hemocyanin concentrations during these particular stages were relatively stable (Engel 1987, Engel \& Brouwer 1987). No subjective segregation of crabs by health, size, or color was made, and 5 to 10 crabs were sampled per site.

Hemolymph samples were collected by severing an appendage between the joints. The appendage of choice was the paddle appendage. The cut was made with a sharp pair of scissors between the joints through the meropodite. The samples were collected in plastic vials, placed on ice, and allowed to clot. The blue crab samples collected in North Carolina were returned to the laboratory on ice and refrigerated. For logistical reasons the Florida and Texas blue crab samples were frozen at $-70^{\circ} \mathrm{C}$, and shipped to Beaufort on dry ice. The clotted hemolymph was homogenized with a Polytron homogenizer, and then centrifuged at $20000 \times g$ for $30 \mathrm{~min}$. The resulting supernate or serum was then decanted and kept at $<4^{\circ} \mathrm{C}$.

The hemocyanin measurements were made spectrophotometrically. The hemolymph serum samples were diluted with buffer, $50 \mathrm{mM}$ Tris $/ 10 \mathrm{mM} \mathrm{CaCl}_{2}, \mathrm{pH} \mathrm{8.0,} \mathrm{and}$ readings taken at 280 and $334 \mathrm{~nm}$. The concentration of hemocyanin was calculated with $E_{280 \mathrm{~nm}}=13.5$ and $E_{334 \mathrm{~nm}}=2.30$ as determined for intact undissociated hemocyanin (Johnson et al. 1984).

Blue crab hemocyanin occurs as a mixture of hexamers and dodecamers. The amount of dodecamers in blue crab populations varies between 88 and $66 \%$ (Mangum et al. 1991), which potentially could affect the absorbance measurements due to light scattering. However, the $280 \mathrm{~nm}$ extinction coefficient of Callianassa californiensis 24-mer hemocyanin is only $5 \%$ greater than the corresponding hexamer (Roxby et al. 1974), showing that light scattering contributes little to the $280 \mathrm{~nm}$ absorbance. Therefore, the contribution due to light scattering for Callinectes sapidus hemocyanin will be negligible.

To measure the nutrient metals copper and zinc and the toxic metal cadmium, digestive glands also were collected from crabs at selected sites and were individually frozen on dry ice in plastic bags. For trace metal analysis, the tissues were dried at $100^{\circ} \mathrm{C}$, wet-ashed in concentrated $\mathrm{HNO}_{3}$, and measured for trace metal concentrations (i.e. cad- mium, copper and zinc) using flame atomic absorption spectrophotometry (Engel \& Brouwer 1987). A standard reference material was used to verify our preparative and analytical measurement techniques for metals.

\section{RESULTS}

\section{Hemocyanin concentrations}

Initial collections of blue crab hemolymph and measurements of hemocyanin concentrations were made in Pamlico Sound during September of 1988. The data showed that the distribution of hemocyanin concentrations in blue crabs from the southwestern portion of the Sound were low relative to the reference area, Beaufort (Fig. 2). The concentration in Beaufort crabs was $62 \mathrm{mg} \mathrm{ml}^{-1}$ while the concentrations in crabs from the tributaries of southwestern Pamlico Sound ranged between 15 and $21 \mathrm{mg} \mathrm{ml}^{-1}$.

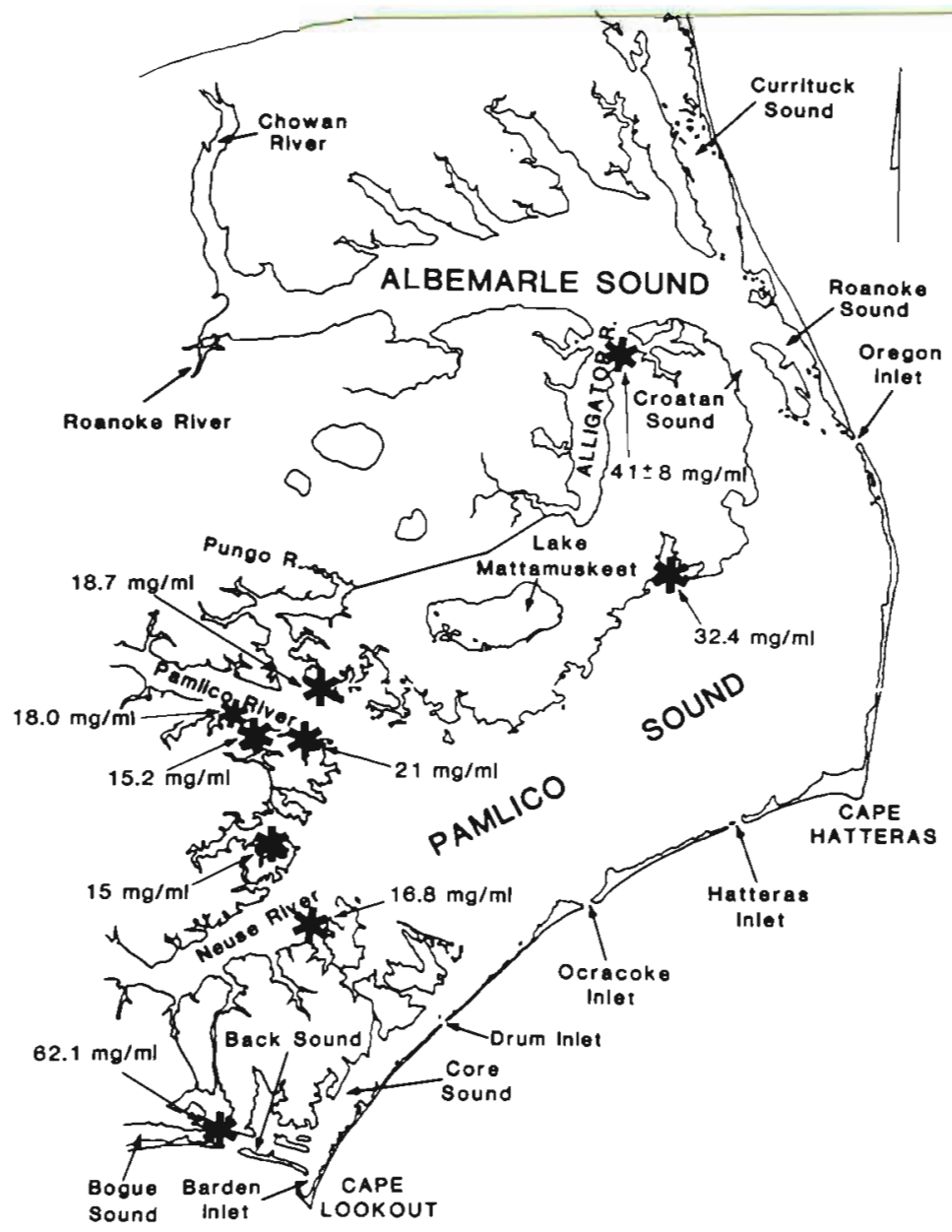

Fig. 2. Map of Albemarle and Pamlico Sounds showing the locations of collection sites and mean hemocyanin concentrations for blue crabs collected in September 1988 


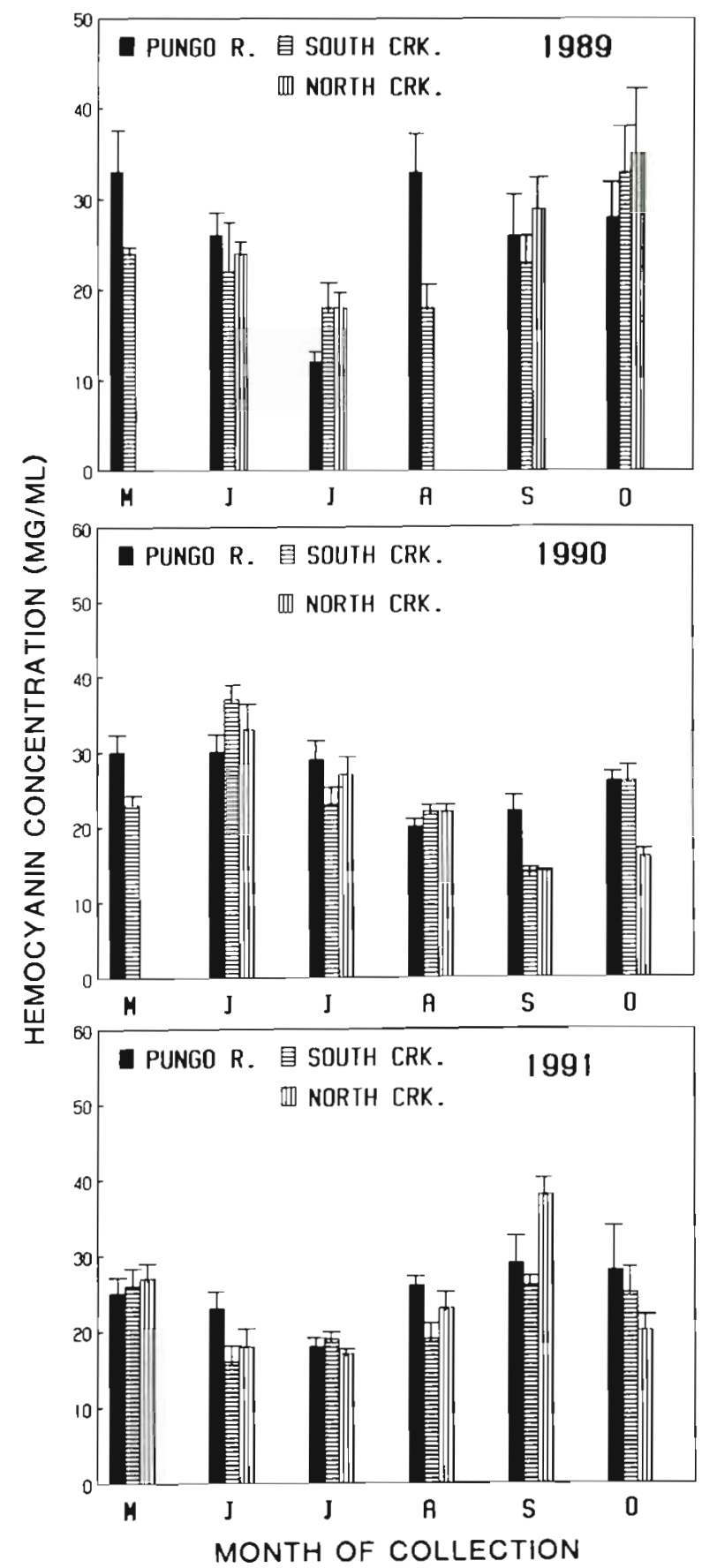

Fig. 3. Callinectes sapidus. Spatial and temporal differences in hemocyanin concentrations in blue crabs collected from the Pamlico River area in 1989, 1990 and 1991. Each monthly data point is the mean of 5 to 10 blue crabs

In 1989, 1990 and 1991, significant spatial and temporal differences occurred within and among the different sampling locations in the Pamlico and Neuse Rivers $(p<0.05)$ (Figs. $3 \& 4)$ and also in the reference areas of Bogue, Core, and Currituck Sounds (Fig. 5). In 1989 the lowest average hemocyanin concentration

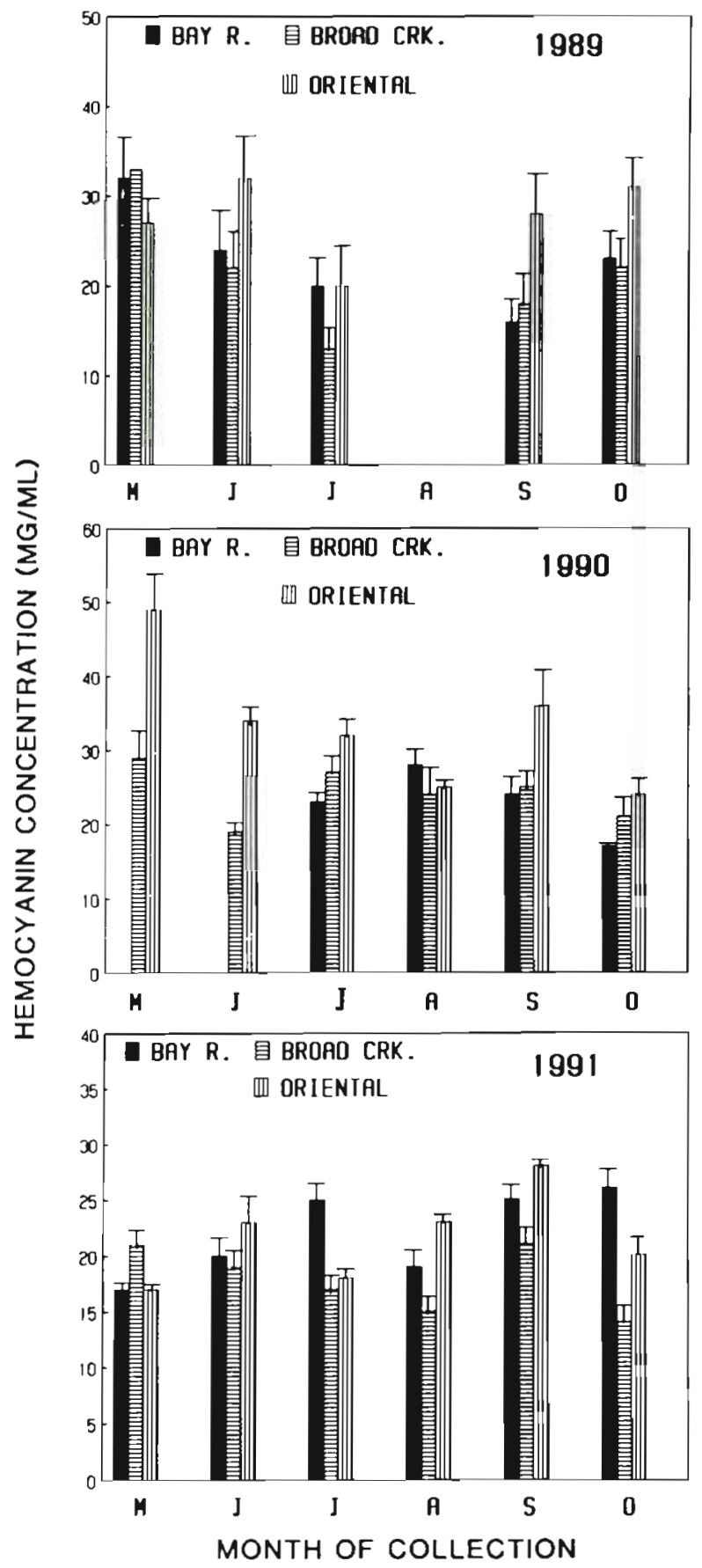

Fig. 4. Callinectes sapidus. As in Fig. 3 but for crabs collected from the Neuse River area

was observed in crabs collected during July from the Pungo River, $13 \mathrm{mg} \mathrm{ml}^{-1}$, and from Broad Creek, $15 \mathrm{mg}$ $\mathrm{ml}^{-1}$, both of which were ca $25 \%$ of the concentration for reference area crabs. Both of the reference areas were high salinity, $>25$ ppt, while the Pungo River and Broad Creek were low salinity, < 15 ppt. In both cases the hemocyanin concentrations rebounded in August and stayed higher through September and October, 


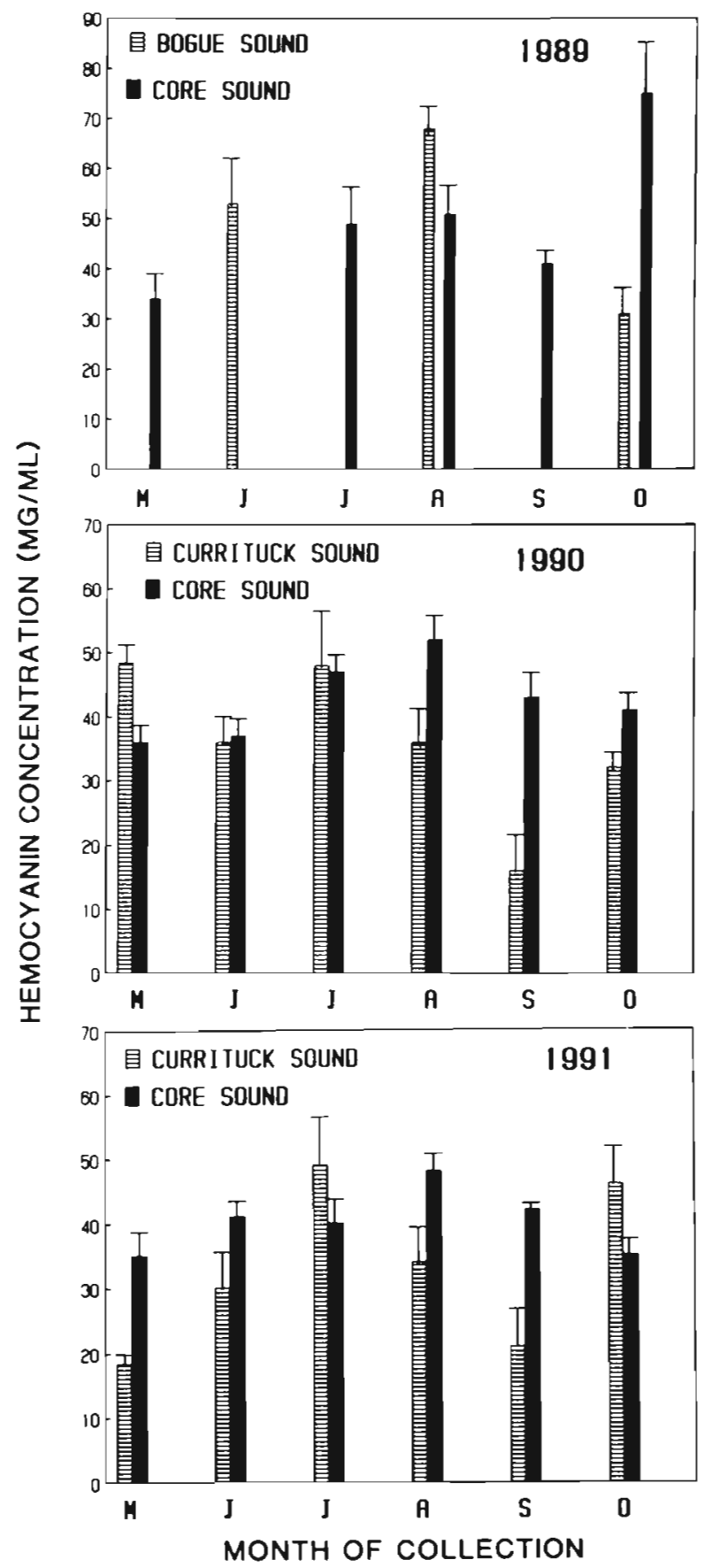

Fig. 5. Callinectes sapidus. As in Fig. 3 but for crabs collected from reference sites

suggesting that recovery had occurred. The differences between the 2 sites on the Neuse River, Broad Creek and Oriental, were particularly interesting, because the lowest value was from the most sparsely populated area, Broad Creek, while Oriental, a harbor having heavy pleasure boat traffic and large marinas, did not vary as greatly. While there were fluctuations in the hemocyanin levels observed in the reference areas (Fig. 5), all measured concentrations were higher than those seen in the Pamlico or Neuse Rivers.

In 1990 there were both spatial and temporal differences in the hemocyanin concentrations measured in crabs from both the Pamlico and Neuse River areas. In the Pamlico system (Fig. 3) the lowest hemocyanin concentrations were measured in crabs collected during August from South and North Creeks. Since these observations were made near the end of the sampling period, it was not determined whether or not the crabs recovered fully. In the Neuse system (Fig. 4) the concentrations fluctuated, but there was no clear temporal or spatial pattern. Measurements of hemocyanin concentrations made on crabs collected from Core and Currituck Sounds remained high (Fig. 5), except for an unexplained low value in Currituck Sound crabs during September.

In 1991 the temporal patterns of hemocyanin concentrations for blue crabs collected from the 3 locations on the Pamlico River were similar to the patterns observed in 1989 (Fig. 3), and once again there were few temporal differences among the 3 sites in the Neuse River area (Fig. 4). The lowest hemocyanin concentrations on the Pamlico River were in June and July at North and South Creeks, and then increased through October at all 3 locations. The hemocyanin concentrations among the Neuse River crabs started low in May relative to 1989 and 1990, and then increased slowly through October. The hemocyanin concentrations among the crabs from Core Sound remained relatively constant throughout the study period, but the Currituck Sound crabs were more variable (Fig. 5). Once again the cause of the observed variability is not known.

Analysis of the blue crab hemocyanin concentrations by ANOVA for 1989, 1990 and 1991 revealed highly significant interactions ( $p<0.001)$ between months and locations (Table 1A). The data from collections for the years 1989 and 1990 indicated that the patterns of change in hemocyanin concentrations over time (months) varied among the locations sampled. In 1991, however, no interaction was detected, nor were there significant differences among locations, but significant differences among months did occur. These results implied that in 1991 there was some consistency among the locations, and that there were patterns of change in hemocyanin over time. For further analysis by ANOVA, the data were grouped by region (Pamlico, Neuse and Reference) (Table 1B). The analysis detected significant Region $\times$ Year $\times$ Month interaction, indicating a lack of consistency in the temporal patterns among regions and years. Examination of mean hemocyanin concentrations reveal that the Pamlico and Neuse regions exhibited similar seasonal patterns in 1989 and 1991. However, in 1990, the 
Table 1. Analyses of variance of blue crab hemocyanin concentrations for 1989 , 1990 and 1991 (A) at all locations by month and (B) in 3 regions by month and year

\begin{tabular}{|c|c|c|c|}
\hline \multicolumn{4}{|c|}{ A. ANOVA - location and month } \\
\hline Source & $\mathrm{df}$ & Mean square & $F$-value \\
\hline \multicolumn{4}{|l|}{1989} \\
\hline Location & 7 & 1509.62 & $7.97^{\cdots}$ \\
\hline Month & 1 & 56.40 & 0.30 \\
\hline Month $\times$ Location & 7 & 1273.57 & $6.72 \cdots$ \\
\hline \multicolumn{4}{|l|}{1990} \\
\hline Location & 7 & 656.12 & $4.12^{\bullet}$ \\
\hline Month & 1 & 1558.96 & $28.63^{\cdots}$ \\
\hline Month $\times$ Location & 7 & 838.24 & $5.26^{\cdots}$ \\
\hline \multicolumn{4}{|l|}{1991} \\
\hline Location & 7 & 84.70 & 0.51 \\
\hline Month & 1 & 1920.88 & $11.53^{\cdots}$ \\
\hline Month $\times$ Location & 7 & 237.28 & 1.12 \\
\hline \multicolumn{4}{|c|}{ B. ANOVA - region, month and year } \\
\hline Source & df & Mean square & $F$-value \\
\hline Region & 2 & 12187.22 & $134.83 \cdots$ \\
\hline Year & 2 & 1956.03 & $15.73^{\cdots}$ \\
\hline Month & 5 & 1733.08 & $6.01^{\cdots}$ \\
\hline Region $\times$ Year & 1 & 1566.28 & $7.25 \cdots$ \\
\hline Region $\times$ Month & 10 & 12137.88 & $7.89^{\cdots}$ \\
\hline Region $\times$ Year $\times$ Month & 25 & 21750.33 & $5.52 \cdots$ \\
\hline$\because$ Significance, $p<0.001$ & & & \\
\hline
\end{tabular}

tions that were correlated positively with the degree of industrialization in Tampa Bay, as shown by sediment PCB concentrations (NOAA, Biological Effects Surveys, 1990) (Table 2). The hemocyanin concentrations were lowest in a highly industrialized area of the Bay (North Hillsborough River) and highest in the middle of the Bay near the inlet to the Gulf of Mexico. This relationship suggests a correlation between water quality or contaminant inputs, as indicated by the degree of industrialization, and hemocyanin concentration.

Hemocyanin concentrations measured in the hemolymph of blue crabs from the Houston Ship Channel at Galveston, Texas, in 1988 were inversely correlated with the distance up the Channel (Fig. 7). There was also an increase in hydrocarbon and trace metal concentrations in the sediments with distance up the Ship Channel (data collected by National Benthic Surveillance Program, Beaufort Laboratory, 1988).
Pamlico region, after reaching a maximum in June, showed a steady decline in average hemocyanin concentration through September. In contrast, the Neuse region declined from a maximum in May to a minimum in June and thereafter exhibited intermediate hemocyanin concentrations until October. With the exception of May, June and September of 1990, the concentrations of hemocyanin in crabs from the Reference region averaged well above those for the other 2 regions.

Six month averages of blue crab hemolymph hemocyanin concentrations for crabs collected in 1989, 1990 and 1991 from the reference and Pamlico/Neuse locations showed the overall differences between test and reference areas (Fig, 6). The pooled data further underscores the persistent nature of the reduced hemocyanin concentrations between years at the different Pamlico/Neuse River locations and the Bogue, Core and Currituck Sound sites. The observed spatial differences in hemocyanin metabolism among blue crabs from locations in Pamlico/Neuse River systems and the reference areas suggest the presence of a combination of natural and/or anthropogenic stressors.

Hemolymph collected from blue crabs at the 4 locations in Tampa Bay had hemocyanin concentra-

\section{Digestive gland metal concentrations}

The concentrations of copper, zinc and cadmium in the digestive glands of crabs collected from the Pamlico River, Bogue and Core Sounds, and the 4 locations in Tampa Bay were different both between and within locations (Table 3). The tissue concentrations of cadmium in Beaufort and Pamlico River blue crabs were not significantly different ( $p>0.05$ ), but both copper and zinc concentrations were significantly higher $(p<0.05)$ among Core and Bogue Sound crabs. Tampa Bay crabs had significantly higher concentrations $(p<0.05)$ of both cadmium and copper than those collected from North Carolina, but the zinc concentrations were similar. Crabs from the more industrialized areas of Tampa Bay (i.e. North Hillsborough Bay) (Fig. 1) had 3 times more copper in the digestive glands than those from the less industrialized portions of the Bay. The high cadmium concentrations in the Tampa Bay crabs relative to those from North Carolina may be related to the larger phosphate mining and processing activity in that portion of Florida. The zinc concentrations in the digestive glands of the blue crabs analyzed in this investigation were similar regardless of the amount of industrial inputs. 


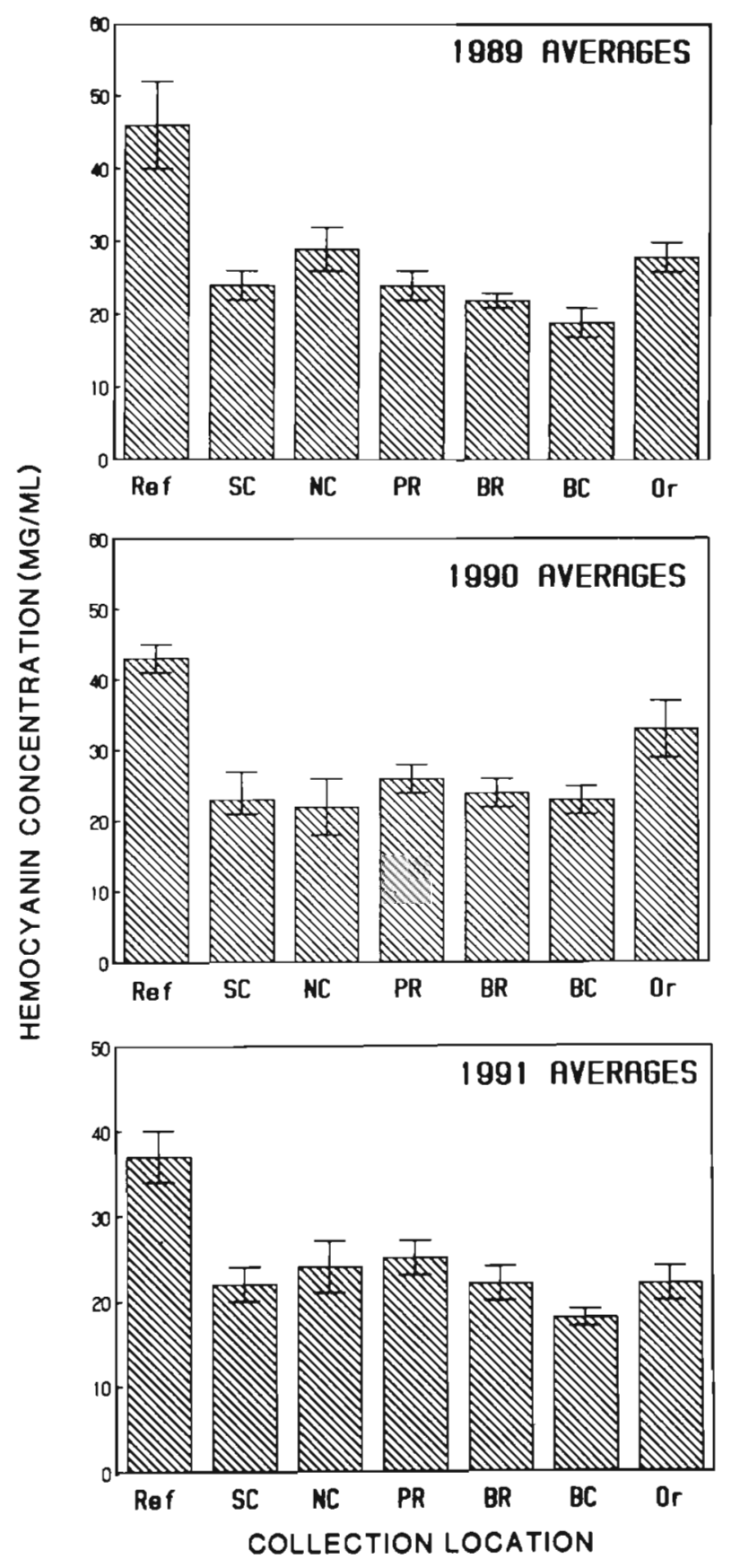

Fig. 6. Callinectes sapidus. Average hemocyanin concentrations measured from reference and Pamlico/Neuse River locations during the 6 mo sampling period for 1989, 1990 and 1991. Vertical bar $=1 \mathrm{SE}$. The locations from left to right are: Ref, reference; SC, South Creek; NC, North Creek; PR, Pungo River; BR, Bay River; BC, Broad Creek; and Or, Oriental

\section{DISCUSSION}

One of the strategies for monitoring the marine environment is to use biological and biochemical measurements in selected organisms as indicators of environmental quality. From our data on blue crabs collected
Table 2. Callinectes sapidus. Hemolymph hemocyanin concentrations from blue crabs collected in 1990 from Tampa Bay, Florida. Concentrations are presented as $\mathrm{mg} \mathrm{ml}^{-1}$ of hemolymph

\begin{tabular}{|lcc|}
\hline Location & $\mathrm{n}$ & $\begin{array}{c}\text { Hemocyanin } \\
\text { concentration }\end{array}$ \\
\hline North Hillsborough Bay & 22 & $48.2 \pm 5$ \\
South Hillsborough Bay & 21 & $54.0 \pm 6$ \\
Old Tampa Bay & 10 & $62.4 \pm 16$ \\
South of Gadsden Point & 25 & $68.9 \pm 6$ \\
& \\
a Locations are arranged in the order of increasing water \\
quality
\end{tabular}

in North Carolina and elsewhere, it appears that the hemolymph hemocyanin concentration is correlated with environmental quality and, therefore, may be a useful indicator of stress. It must be emphasized that 'stress' may include a number of natural and anthropogenic factors which may or may not interact to cause the observed response.

Hemocyanin concentrations in blue crabs from degraded environments (i.e. the Houston Ship Channel and North Hillsborough Bay, Tampa) are reduced relative to hemocyanin concentrations in crabs from 'cleaner' reference areas. Unlike the 2 above mentioned locations where there is a direct correlation between industrial contaminant inputs and low hemocyanin concentrations, the North Carolina crabs are not exposed to such conditions. In fact, the lowest hemocyanin concentrations have been measured in crabs collected from sparsely populated areas, which implicates a cause other than chemical contaminants.

The data that has been collected in the southwestern Pamlico Sound and its tributaries shows that there are both spatial and temporal differences in the hemocyanin concentrations among the blue crab population in

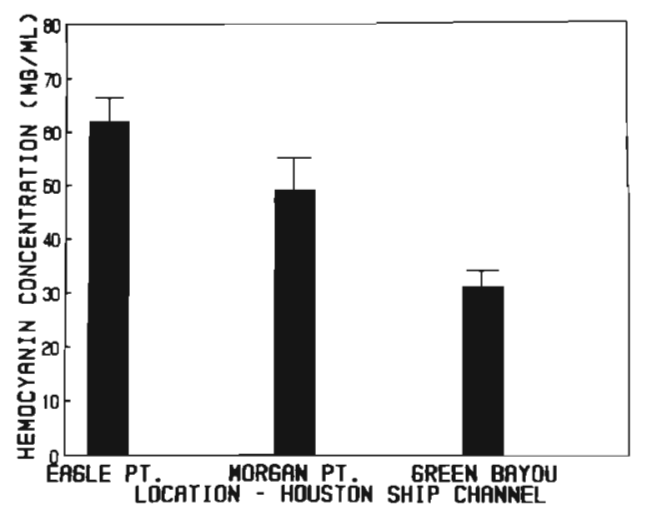

Fig. 7. Callinectes sapidus. Average hemocyanin concentrations for blue crabs collected in the Houston Ship Channel in 1988. Each value is the mean of 6 individual crabs +1 SE 

Pamlico River and Tampa Bay. Concentrations in $\mathrm{mg} \mathrm{kg}^{-1}$ wet weight $\pm \mathrm{SE}$

\begin{tabular}{|lccrc|}
\hline Location & $\mathrm{n}$ & $\mathrm{Cd}$ & $\mathrm{Cu}$ & $\mathrm{Zn}$ \\
\hline $\begin{array}{l}\text { Beaufort (Core and } \\
\text { Bogue Sounds, NC) }\end{array}$ & 28 & $2.07 \pm 0.3$ & $20.1 \pm 1.7$ & $43.5 \pm 3.8$ \\
$\begin{array}{l}\text { Pamlico River, NC } \\
\text { Tampa Bay, FL }\end{array}$ & 35 & $2.09 \pm 0.2$ & $4.6 \pm 0.3$ & $30.2 \pm 3.0$ \\
$\quad$ N. Hillsborough Bay & 22 & $7.4 \pm 0.6$ & $165.0 \pm 28$ & $46.8 \pm 4.4$ \\
S. Hillsborough Bay & 21 & $8.0 \pm 0.6$ & $90.4 \pm 15$ & $36.6 \pm 2.9$ \\
Old Tampa Bay & 10 & $5.7 \pm 1.1$ & $89.2 \pm 19$ & $43.0 \pm 4.5$ \\
Gadsden Point & 25 & $9.2 \pm 0.8$ & $50.0 \pm 10$ & $48.9 \pm 3.2$ \\
\hline
\end{tabular}

Table 3. Callinectes sapidus. Concentrations of trace metals (cadmium, copper, zinc) in the digestive glands of blue crabs collected from the Beaufort area, the

tuations. Therefore, crabs from the Pamlico system with salinities of 7 to $14 \mathrm{ppt}$ would be expected to have higher hemocyanin concentrations than those collected from the high salinity reference area. Instead, crabs from the Pamlico/Neuse systems tend to have lower hemocyanin concentrations.

The lack of oxygen, hypoxia, becomes a prime candidate as the causative agent for reduced hemocyanin concentrations in the Pamlico/Neuse systems. The effects of

this area. Low concentrations of hemocyanin were first measured in September 1988 in crabs from different locations in Pamlico Sound in a single set of collections. Other collections made during the summers of 1989 , 1990 and 1991 at similar locations showed similar trends. In all 3 data sets, significant differences $(p<0.05)$ in hemocyanin concentrations were demonstrated both between and within sampling locations. The lowest concentrations tended to occur during July and August when the water temperatures tend to be the highest, and then increase in September and October as the water cools (data supplied by the N.C. Division of Environmental Management and the Division of Marine Fisheries). Temperature and dissolved oxygen measurements made in the Pamlico and Neuse Rivers (Garrett \& Bales 1991) show that the lowest bottom and midwater dissolved oxygen and highest temperatures were measured in June and July in 1989 and in August and September in 1990. These data correlate well with the lowest hemocyanin concentrations measured in blue crabs collected from areas close to where oxygen-temperature data was obtained. Such a correlation strongly implicates dissolved oxygen and temperature as contributing factors to the reduced hemocyanin concentrations.

Reduced salinity, 3 to $12 \mathrm{ppt}$, which routinely occurs in the study area, has been shown to positively affect the synthesis of hemocyanin in blue crabs exposed under laboratory conditions (Engel et al. in press, $\mathrm{M}$. Brouwer unpubl. data, Charlotte Mangum, College of William and Mary, pers. comm.). In laboratory tests, we demonstrated that crabs acclimated to high salinity, $32 \mathrm{ppt}$, and then transferred to $5 \mathrm{ppt}$ had a $14 \%$ increase in hemocyanin concentration after $21 \mathrm{~d}$ of exposure. Hemocyanin concentrations measured in blue crabs from a low salinity estuary on the Gulf of Mexico support the above mentioned laboratory observations (Heron Bay, MS, low salinity, hemocyanin $71 \mathrm{mg} \mathrm{m}^{-1}$ ). Also, the low salinity (1 to $3 \mathrm{ppt}$ ) reference area in Currituck Sound tended to have higher hemocyanin concentrations despite some unexplained fluc- prolonged hypoxia on hemocyanin concentrations in marine crustaceans, however, are not clearly defined. DeFur et al. (1990) have shown in laboratory tests that hypoxia can cause increased hemocyanin concentrations in blue crabs collected from Chesapeake Bay, USA, where hypoxic conditions occur routinely. Brouwer and coworkers exposed blue crabs to reduced oxygen ( $30 \%$ of saturation) for $21 \mathrm{~d}$ and did not show any significant increase in hemocyanin concentration (unpubl. data). Hagerman (1986) demonstrated that chronic hypoxia caused increases in hemocyanin concentrations in Crangon crangon, but also showed that starvation will decrease hemocyanin concentrations. In contrast, Hagerman \& Baden (1988) demonstrated that low oxygen caused reduced feeding and lowered hemocyanin concentrations in Nephrops norvegicus. In a later study, Baden et al. (1990) showed that moderate hypoxia (20 to $40 \% \mathrm{O}_{2}$ saturation) caused an increase in hemocyanin, but that severe hypoxia (10 to $20 \% \mathrm{O}_{2}$ saturation) caused a decrease.

Data on dissolved oxygen concentrations, temperatures, and hemocyanin concentrations in crabs collected at South Creek in 1989 (oxygen and temperature data supplied by the N.C. Division of Environmental Management) showed a positive correlation between increased temperatures and low dissolved oxygen and lowered hemocyanin concentrations (Fig. 8). In 1991 there also appears to be correlation between lowest hemocyanin concentrations and the months when the highest temperatures and lowest oxygen concentrations occurred (data collected by N.C. Division of Marine Fisheries). It is our hypothesis that hypoxia alone did not cause the observed reduction in hemocyanin, but that it is an indirect effect of a combination of hypoxia-induced torpor, reduced feeding, and thermally accelerated metabolism. Uglow (1969) demonstrated that imposed fasting in Cancer maenas resulted in catabolism of hemocyanin and its use as a nitrogen source. Similar effects also were observed in overwintering blue crabs from eastern North Carolina (Engel \& Brouwer 1987). 


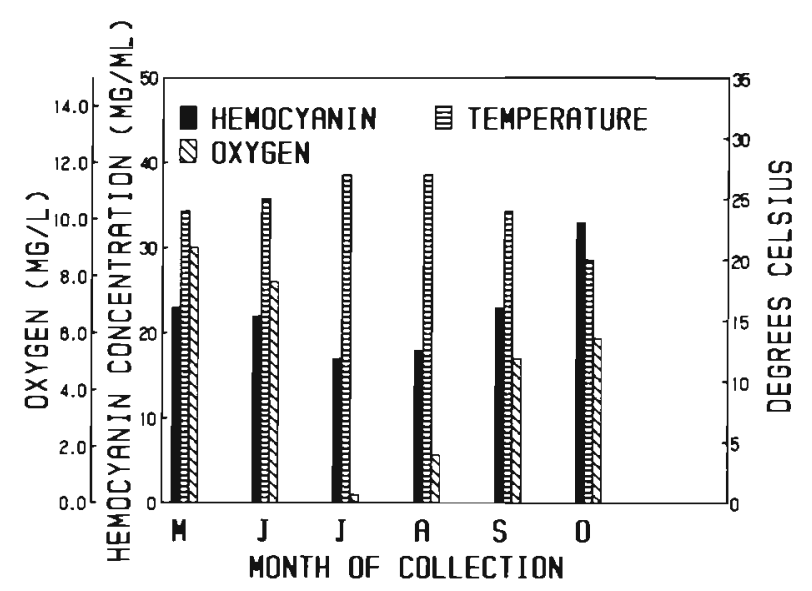

Fig. 8. Callinectes sapidus. Relationship between blue crab hemolymph hemocyanin concentrations and water temperature and dissolved oxygen concentrations on South Creek in 1989. Hemocyanin measurements are the same as in Fig. 2. Temperature and dissolved oxygen data was collected by the N.C. Division of Environmental Management at a location in the vicinity of where the blue crabs were collected by otter trawl. Both the oxygen and temperature data was collected at a depth of $4 \mathrm{~m}$

When the crabs were collected in the early spring the hemocyanin was lower by about $30 \%$, but rebounded rapidly after feeding began in the laboratory.

In addition to 'natural' environmental factors that can cause reductions in hemocyanin concentrations in blue crabs, organic contaminants, particularly petroleum hydrocarbons and pesticides, also may be implicated. These contaminants may exert their influence by inhibiting normal copper metabolism and thus the synthesis and turnover of hemocyanin in blue crabs. Recently it has been shown that glutathione, a compound that has long been known to play a role in the detoxification of certain aromatic hydrocarbons (PAHs) (Meister \& Anderson 1983), also is involved in copper metabolism (Freedman et al. 1989). In our laboratory we demonstrated that a complex of $\mathrm{Cu}(\mathrm{I})$ and glutathione can reactivate copper-free hemocyanin (Brouwer \& Brouwer-Hoexum 1991, 1992). In addition, it has been reported that the digestive gland levels of the enzyme glutathione-S-transferase, which conjugates hydrocarbons with glutathione, increased when blue crabs were exposed to an organic contaminant, 2,6ditertiary-butyl-4-hydroxytoluene (BHT) (Lee et al. 1988). This information suggests a possible pathway by which exposure to PAHs and pesticides and their subsequent detoxification may result in diminished hemocyanin synthesis, due to the lack of $\mathrm{Cu}(\mathrm{I})$-glutathione complexes.

The measured hemocyanin concentrations in the hemolymph of blue crabs collected in the Houston Ship Channel and Tampa Bay support the hypothesis that organic contaminants may be involved in alteration of hemocyanin metabolism. The data from Texas showed a negative correlation between the distance up the Houston Ship Channel and hemocyanin concentrations in the crabs. In addition to the increased inorganic and organic contaminants in sediment and decreased dissolved oxygen concentrations up the Ship Channel toward Houston, Burke et al. (in press) showed that among fish collected from the same locations in 1988 growth was reduced and fin erosion increased. Both sets of biological measurements reflect effects of a degraded environment which includes both elevated chemical contaminants and decreased dissolved oxygen.

In Tampa Bay there was a direct relationship between measured organic contaminants in crab tissues and hemocyanin concentrations among the blue crabs collected. The digestive glands were taken from crabs collected from North and South Hillsborough Bays and Gadsden Point and composited and analyzed for PCBs and DDT (Susan Pierce, NMFS/Northwest Fisheries Center, Seattle Laboratory, unpubl. data). Both PCBs and DDT were highest at North Hillsborough Bay (2600 and $740 \mathrm{ng} \mathrm{g}^{-1}$ ) and lowest at Gadsden Point (990 and $250 \mathrm{ng} \mathrm{g}^{-1}$ ) which correlates negatively with the measured concentrations of hemocyanin (Table 2). These data support the idea that detoxification of organic contaminants may interfere with normal copper metabolism in the blue crab, since the crabs with highest copper and PCB/DDT concentrations have the lowest hemocyanin concentrations.

While the data from Tampa Bay indicates a possible direct relationship between organic contaminant concentration and reduced hemocyanin, the data from North Carolina blue crabs suggests an indirect route for the alteration of normal hemocyanin metabolism in blue crabs. Among the North Carolina crabs there is a correlation between lower copper and hemocyanin concentrations in Pamlico River crabs, and higher copper and hemocyanin concentrations in crabs from the Reference sites, Core and Bogue Sounds (Table 2 and Figs. $2 \& 6$ ). The forcing function among the Pamlico River crabs appears to be an interaction between low dissolved oxygen and elevated temperature. We also have observed this same type of relationship in another estuary, New River, on the southern coast of North Carolina (Engel et al. in press). The crabs from the New River have significantly lower hemocyanin concentrations than adjacent estuaries with similar salinities. In the New River, the probability of hypoxic conditions in the estuary is exacerbated by the effluents from 3 sewage treatment plants and poor tidal flushing (N.C. Division of Environmental Management, Wilmington Office, Wilmington, NC). Zinc was not affected in blue crabs by environmental factors to as great an extent as copper. The data collected to date 
indicates that zinc does not vary greatly among different blue crab populations.

At this time we cannot document a specific cause and effect relationship that can explain all of the observed reductions in blue crab hemocyanin concentrations from different geographical areas. Our data, however, does provide evidence for a positive correlation between hypoxic conditions and elevated water temperatures and lowered hemocyanin concentrations. In addition, there is also evidence that organic contaminants can negatively affect copper metabolism and therefore, hemocyanin turnover. While the response of the crabs to aberrant environmental conditions is variable, we have been able to demonstrate consistent results over time in North Carolina. The physiological/toxicological processes that control the turnover and synthesis of hemocyanin in the blue crab are complex, but appear to be sensitive to environmental conditions.

Acknowledgements. The authors thank Mr Bill Bowen and Mrs Thea Brouwer for their assistance in this project and Dr David R. Colby for statistical counseling and data analysis. We also thank the North Carolina Division of Marine Fisheries, Dr William Hogarth; the North Carolina Division of Environmental Management, Mr Jimmie Overton; the NOAA, National Status and Trends Benthic Surveillance Program, Beaufort Laboratory, Dr Peter Hanson; and the NOAA Bioeffects Survey, NOAA/NMFS, Seattle Laboratory, Dr Bruce McCain for the collection of blue crab hemolymph samples in 1988, 1989, 1990 and 1991 and the collection temperature/ salinity/dissolved oxygen measurements. Use of trade names does not constitute an endorsement by the Department of Commerce and the National Marine Fisheries Service. These investigations were funded wholly or in part by the National Marine Fisheries Service and the E.P.A. Albemarle/Pamlico Estuarine Study (Project \# 92-09) respectively.

\section{LITERATURE CITED}

Baden, S. P., Pihl, L., Rosenberg, R. (1990). Effects of oxygen depletion on the ecology, blood physiology and fishery of the Norway lobster Nephrops norvegicus. Mar. Ecol. Prog. Ser. 67: 141-155

Brouwer, M. (1992). Oxygen carriers as molecular models of allosteric behavior Adv. comp environ. Physiol. 13: 1-26

Brouwer, M., Brouwer-Hoexum, T. M. (1991). Interaction of copper-metallothionein from the American lobster, Homarus americanus, with glutathione. Arch. Biochem. Biophys. 290: 207-213

Brouwer, M., Brouwer-Hoexum, T M. (1992). Glutathionemediated transfer of $\mathrm{Cu}(\mathrm{I})$ into American lobster hemocyanin. Biochemistry 31: 4096-4102

Brouwer, M., Winge, D. R., Gray, R. W. (1989). Structural and functional diversity of copper-metallothioneins from the American lobster Homarus americanus. J. inorg. Biochem. 35: $289-303$

This article was presented by J. Vernberg, Columbia, S. Carolina, USA
Burke, J. S., Peters, D. S., Hanson, P. J. (1993). Morphological indices and otolith microstructure of Atlantic croaker, Micropogonias undulatus, as indicators of habitat quality along an estuarine pollution gradient. Environ. biol. Fish. 36: $25-33$

DeFur, P. L., Mangum, C. P., Reese, J. E. (1990). Respiratory responses of the blue crab Callinectes sapidus to longterm hypoxia. Biol. Buld. 178: 46-54

Ellerton, D. H., Ellerton, N. F., Robinson, H. A. (1983). Hemocyanin - a current perspective. Prog. Biophys. mol. Biol. $41: 143-248$

Engel, D. W. (1987). Metal regulation and molting in the blue crab, Callinectes sapidus: copper, zinc, and metallothionein. Biol. Bull. 172: 69-81

Engel, D. W., Brouwer, M. (1987). Metal regulation and molting in the blue crab, Callinectes sapidus: metallothionein function in metal metabolism. Biol. Bull. 173: 339-351

Engel, D. W., Brouwer, M. (1991). Short-term metallothionein and copper changes in blue crabs at ecdysis. Biol. Bull. 180: $447-452$

Engel, D. W., Brouwer, M. (1993). Crustaceans as models for metal metabolism. I. Effect of the molt cycle on blue crab metal metabolism and metallothionein. Mar. environ. Res. 35: $1-5$

Engel, D. W., Brouwer, M., Noga, E. J., Stevens, J. B. (in press). Blue crab, Callinectes sapidus, hemocyanin concentrations as a measure of environmental quality in the Albemarle/Pamlico estuary. Annual Report to EPA Albemarle/Pamlico Estuarine Study

Freedman, J. H., Ciriolo, M. R., Peisach, J. (1989). The role of glutathione in copper metabolism and toxicity. J. biol. Chem. 264: 5598-5605

Garrett, R. G., Bales, J. D. (1991). Water-quality data from continuously monitored sites in the Pamlico and Neuse River estuaries, North Carolina, 1989-90. AlbemarlePamlico Estuarine Study, North Carolina Department of Environment, Health, and Natural Resources. U.S. Geological Survey, Open-File Report 91-465

Hagerman, L. (1986). Hemocyanin concentration in the shrimp Crangon crangon (L.) after exposure to moderate hypoxia. Comp. Biochem. Physiol. 85A: 721-724

Hagerman, L., Baden, S. P. (1988). Nephrops norvegicus: field study of effects of oxygen deficiency on haemocyanin concentration. J. exp. mar. Biol. Ecol. 116: 135-142

Johnson, B. A., Bonaventura, C., Bonaventura, J (1984). Allosteric modulation of Callinectes sapidus hemocyanin by binding L-lactate. Biochemistry 23: 872-878

Lee, R. F., Keeran, W. S., Pickwell, G. V. (1988). Marine invertebrate glutathione-S-transferases. Purification, characterization and induction. Mar. environ. Res. 24: 97-100

Mangum, C. P., Greaves, J., Rainer, J. S. (1991). Oligomer composition and oxygen binding of the hemocyanin of the blue crab Callinectes sapidus. Biol. Bull. 181: 453-458

Meister, A., Anderson, M. E. (1983). Glutathione. Ann. Rev. Biochem. 52: 711-760

Roxby, R., Miller, K., Blair, D. P., Van Holde, K. E. (1974). Subunits and association equilibria of Callianassa californiensis hemocyanin. Biochemistry 13: 1662-1667

Uglow, R. F. (1969). Haemocyanin protein concentrations in portunid crabs. II. The effect of imposed fasting on Carcinus maenas. Comp. Biochem. Physiol. 31: 959-967

Van Holde, K. E., Miller, K. (1982). Haemocyanins. Q. Rev. Biophys. 15: 1-70

Manuscript first received: April 15, 1992

Revised version accepted: December 17, 1992 